\title{
MSMEs and Employment in India: an analytical study
}

\author{
Dr. Uma Pujar M.Com., Ph.D. \\ Assistant Professor Of Commerce Government First Grade College, Dharwad Karnataka, India.
}

\begin{abstract}
Entrepreneur is one of the vital inputs in the economic growth and development of a country. Country like India, where mixed economic system exists, that is where State and Private entrepreneurship coexist, the small industrial sectors and business are left in the hands of private entrepreneurs. The micro small and medium entrepreneurs help in the development of economy by creating employment, which in turn leads to eradication of looming problems like unemployment, regional disparities and poverty of the country. Entrepreneur is a person who innovates and come out with over all change by increasing the standard of living for the betterment of the society by investing and taking lot of risk.

Micro Small and Medium scale industries has been playing a very important role in the social and economic development of the country. They are considered as the main indicator for the economic development of developing country like India. It has significantly contributed to the overall growth in terms of Gross domestic product, employment generation, income distribution, rural development, poverty eradication, exports and regional balance. It is one of the most vital sectors of the Indian economy in terms of employment generation and providing strong entrepreneurial base. It is estimated that in terms of value, the MSME sector accounts for about $45 \%$ of manufacturing outputs and $40 \%$ of the total exports of the country. Employment distributed is about 595 lakh persons in over 261 lakh enterprises throughout the country. There are over 6000 products ranging from tradition to high-tech items, which are being manufactured by MSMEs in India. It is well known that the MSME provide good opportunities for both self employment and wage employment. Further, this sector has consistently registered a higher growth rate than the rest of the industrial sector. The paper used secondary data and based on descriptive research methodology. Secondary data from various government journals, SIDBI Annual report, MSME Act and various five year plans are used. The main objective of the present study is to analyze the role of MSME sectors in generating employment in India.
\end{abstract}

Key words: Employment, MSMEs,

\section{Introduction}

Growth and development of MSMEs is vital for healthy growth of our economy. The main objectives behind creating MSMEs are the creation of job opportunities increase standard of living, regional balance, mobilization of local skills and capital etc... It has contributed most significantly for the development and promotion of first generation enterprises. Promotion of Small scale industries has been one of the main strategies for economic development of the developing countries since 1950s. MSMEs are able to tap latent resources and makes use of indigenous resources for producing goods and services. They act as a backbone or an engine for the economic growth and development of the country. It is estimated that in terms of value, the MSME sector accounts for about $45 \%$ of manufacturing outputs and $40 \%$ of the total exports of the country. Employment distributed is about 595 lakh persons in over 261 lakh enterprises throughout the country. There are over 6000 products ranging from tradition to high-tech items, which are being manufactured by MSMEs in India.

\section{Objective}

The main objective of the present study is to analyze the role of MSME sector in generating employment in India.

\section{Methodology}

The present study is based on secondary data. The secondary data are collected from the website of the Ministry of Small and Medium Enterprises, the government of India and Final Report, fourth All India Census of MSME 2006-2007: Registered sector. The study is based on fourth census MSME sector and highlights the Role of MSME sector in India. 
MSMEs and Employment in India: an analytical study

Table - 1 Distribution Of Msme Employment In Rural And Urban Areas
\begin{tabular}{|c|c|c|c|c|c|}
\hline Area/sector & Micro & Small & Medium & $\begin{array}{c}\text { Total working } \\
\text { enterprises } \\
\text { (in lakh) }\end{array}$ & $\begin{array}{c}\text { Employment } \\
\text { (in lakh) }\end{array}$ \\
\hline Rural & 6.87 & 0.19 & 0.01 & $7.07(45)$ & $36.82(39.55)$ \\
\hline Urban & 7.98 & 0.57 & 0.02 & $8.57(55)$ & $56.27(60.45)$ \\
\hline All & 14.85 & 0.76 & 0.03 & $15.64(100)$ & $93.09(100)$ \\
\hline
\end{tabular}

Source: Final Report, fourth All India Census of MSME 2006-2007: Registered sector.

Table -1 depicts the distribution of working enterprises and employment in rural urban areas. Urban areas with 8.57 lakh of working enterprises accounted for 55 percent of the total working enterprises in MSME sector. Employment in Urban area is 56.27 lakh persons, accounting for 60.45 percent of total employment in MSME sector. Whereas rural areas located 7.07 lakh working enterprises that is, 45 percent of working enterprises in MSME sector. Employment in Rural area is 36.82 lakh persons, accounting 39.55 percent of total employment in MSME sector.

Table - 2 Distribution Of Employment By Sector Wise

\begin{tabular}{|c|c|c|}
\hline Sector & $\begin{array}{c}\text { No. of Enterprises } \\
\text { (In lakh) }\end{array}$ & $\begin{array}{c}\text { Employment } \\
\text { (in lakh) }\end{array}$ \\
\hline Micro & $14.85(94.94)$ & $65.34(70.19)$ \\
\hline Small & $0.76(4.89)$ & $23.43(25.17)$ \\
\hline Medium & $0.03(0.17)$ & $4.32(4.64)$ \\
\hline Total & $15.64(100)$ & $93.09(100)$ \\
\hline
\end{tabular}

Source: Final Report, fourth All India Census of MSME 2006-2007: Registered sector.

Table- 2 depicts the distribution of working Enterprises and Employment by sectors. Micro sector with 14.85 lakh working enterprises, accounted for $94.94 \%$ of total working MSMEs and with 65.34 lakh employment, accounting for 70.19 percent of total MSMEs. The micro enterprises dominate in terms of number of working enterprises and employment. The small and medium sectors bagged 0.76 lakh and 0.03 lakh working enterprises, accounting $4.89 \%$ and $0.17 \%$ of working enterprises in MSME sector respectively.

Table - 3 Distribution Of Employment By Type Of Activity In Msme Sector

\begin{tabular}{|c|c|c|}
\hline Activity & $\begin{array}{c}\text { No. of Enterprises } \\
\text { (In lakh) }\end{array}$ & $\begin{array}{c}\text { Employment } \\
\text { (In lakh) }\end{array}$ \\
\hline Manufacturing & $10.50(67.10)$ & $80.83(86.83)$ \\
\hline $\begin{array}{c}\text { Repair and } \\
\text { Maintenances }\end{array}$ & $2.52(16.13)$ & $6.28(6.75)$ \\
\hline Services & $2.62(16.77)$ & $5.98(6.42)$ \\
\hline Total & $15.64(100)$ & $93.09(100)$ \\
\hline
\end{tabular}

Source: Final Report, fourth All India Census of MSME 2006-2007: Registered sector.

Table 3 shows the Distribution of Enterprises and employment by type of activity in the MSME sector. The Manufacturing enterprises dominate in terms of number of enterprises and employment, when compared with other two activities. Number of enterprises in manufacturing activity is 10.50 lakh accounting for 67.10 percent, employment with 80.83 lakh persons accounting for 86.83 percent from the total MSMEs sector.

\section{Findings}

1. Micro sector with 94.94 percent of enterprises of registered MSME sector was the most dominant segment in terms of number of enterprises. This sector also accounted for the largest and very dominant share of employment $(70.19 \%)$ of registered MSME sector. Thus micro sector was a very important segment of MSME sector in terms of number of enterprises and employment.

2. Urban areas had a larger share of registered MSME sector as compared to rural areas in respect of two major parameters such as number of enterprises and employment. Employment in Rural area is 36.82 lakh persons, accounting 39.55 percent of total employment in MSME sector.

3. Under the type of activity based distribution the Manufacturing enterprises dominate in terms of number of enterprises and employment when compared with repair and maintenances and service activities. 


\section{Conclusion}

The MSMEs has a distinct privilege of low investment with high potential to create employment generation. It also helps in eradicating regional imbalances by dispersal of industries in rural areas. The Indian economy can look forward to a prosperous future in MSME sectors. Specially, micro enterprises, which substantially play a basic role in employment generation and bring forth the entrepreneurship at grass root level. These sectors should be given pre-eminent role and must be pampered extensively. These enterprises are labour intensive and require less capital, helps in eradicating socio-economic problems like unemployment, underemployment, poverty and regional imbalances. This sector should get proper infrastructure and other support from the Government for proper promotion and development.

\section{References}

[1]. Desai, Vasant (2008), "Small- Scale Industries and Entrepreneurship", Himalaya Publishing House, New Delhi.

[2]. Sushma Rani Verma "Performance of Haryana Financial Corporation in Liberalized Era", the IUP Journal of Managerial Economics, Vol. VIII, 2010.

[3]. Jayant Sathaye and Ashok Gadgil, "Role of Development Banks in Promoting Industrial Energy Efficiency India Case Studies", Ernest Orlando Lawrence Berkeley National Laboratory, 1999.

[4]. Dr.H.Y.Kamble, Role of Karnataka a State Financial Corporation in the Industrial Development of the State, Indian journal of Commerce, Vol. L,No. 192, Part III Sept. 1997,P.104-110 